\title{
NEW APPROACHES TO THE CONTROL OF OLIGOPOLY *
}

\section{Louts B. Schwartz $†$}

Every undertaking to prohibit, regulate, or control monopoly and restraint of trade must approach the subject from two points of view: structure and practices. ${ }^{1}$ From the point of view of structure, legislation must seek to prevent concentration of private control of markets into too few hands-that is, to prevent mergers and other relatively rigid unifications of interest and management, and to break up existing excessive concentrations. From the point of view of practices, the aim must be to prevent certain types of concerted action by agreement or understanding among independent firms whose size alone presumably does not offend the rules as to industry structure.

It is remarkable that this two-level operation of the antitrust laws may permit a structural change-a unification of firms by merger or holding company control-where it would not tolerate restrictive agreements between the same firms, although the market control involved in the latter arrangement is far less comprehensive and enduring and presumably, therefore, less dangerous. The explanation for this paradox is said to be that unifications often have technological justifications, especially economies of scale, which we do not wish to limit by law. A startling consequence of this paradox of antitrust regulation is that the enactment of a law preventing temporary combinations is likely to lead to a wave of mergers and permanent consolidations to replace the newly forbidden restrictive agreements. The process of consolidation will go on to the limit of the law. Where this limit is high, as it has been in the United States, major industries will typically come to be dominated by two, three, or four firms-that is, by an oligopoly. Economists tell us that oligopolies function like monopolies, or as if there were agreements among the leading firms even though no such agree-

* This Article is adapted from a paper given at the International Conference on Restraints of Competition, sponsored by the Institute for Foreign and International Trade Regulation, and held in Frankfurt, Germany, during June 1960. The author gratefully acknowledges the assistance of Silas Spengler, Class of 1960, University of Pennsylvania Law School, in preparing this Article for publication and especially in compiling the tables which appear in the appendices.

$\dagger$ Professor of Law, University of Pennsylvania. A.B. 1932, LL.B. 1935, University of Pennsylvania.

1 The problem is reviewed in Johnston \& Stevens, Monopoly or MonopolizationA Reply to Professor Rostow, 44 IIL. L. REv. 269 (1949); Levi, A Two Level Anti-Monopoly Law, 47 Nw. U.L. Rev. 567 (1952); Rostow, Monopoly Under the Sherman Act: Pozver or Purpose, 43 IL.. L. REv. 745 (1949). 
ments exist. Through price leadership, mutual deference, fear, or simple recognition of what is in their common interest, they will maintain prices above competitive levels, refuse to supply new distributors, and postpone introduction of new and cheaper techniques involving the rapid obsolescence of old investment.

Faced with this situation, a government having an antitrust policy must make up its mind whether: (1) to revise the structural part of its antitrust law so that it does not tolerate "oligopoly"; (2) to revise the practices part of its antitrust law so that coordinated action which would be illegal when done by agreement becomes illegal without proof of agreement; (3) to do nothing about the situation, on the theory that concentration to the level of oligopoly is necessary to achieve economies of scale and thus serves the public interest notwithstanding the impairment of competition; or (4) to establish public control of price and other economic decisions of "oligopolists" to prevent abuse of the monopolistic power which it is said they inherently possess.

Which course should be taken depends on what we know about oligopolies, the ease and precision with which they can be identified, their effects, and the extent to which other forces in the economy may counteract their monopolistic tendencies. These are economic problems. The lawyer's problem is to translate such knowledge into comprehensible and effective regulation. How the legislators, judges, administrators, and lawyers of different countries have essayed this task will be discussed later in this Article, after we have first examined the state of economic knowledge in the field.

When is an industry properly characterized as oligopolistic or dangerously oligopolistic? As might be expected, no firm and clear answer can be given. The variables in the economic formula are too numerous and each of the variables is difficult to measure. In the first place, there are the difficulties of defining an "industry" and securing the relevant statistics. ${ }^{2}$ The more firms and products we lump together in a single industry, the smaller will seem the share of any one firm or group of firms. Are steel, aluminum, and copper separate industries? Or are they, because of a degree of interchangeability, to be considered a single field of "basic metals"? Or should we draw the industry

2 As to the various bases on which concentration may be calculated, compare FTC, Report on the Concentration of Productive Facilitiss (1947) (percentage of industry's net capital assets), with KAYSEN \& TURner, ANTITRUST Policy: AN ECONOMIC AND Legal ANALYSIS (1959) (percentage of total market sales). Extracts from both studies are set forth in the appendices to this Article. See also the three articles in National Bureau of Economic Researce, Business ConCEntration AND Price Policy (1955): Miller, Measures of Monopoly Power and Concentration: Their Economic Significance at 119; Rosenbluth, Measures of Concentration at 57; and Scitovsky, Economic Theory and the Measurement of Concentration at $10 \mathrm{i}$. 
boundaries with reference to particular forms of fabrication, so that we differentiate an iron industry from a steel industry, and treat "wire and cable" as one industry embracing products made of steel, aluminum, or copper? ${ }^{3}$

When we have determined what products and firms to consider as single industries, we must also calculate the geographic boundaries of their "markets," because firms making even identical products in different territories, isolated from each other, do not act as competitive checks upon each other. The important word here is "isolated": market regions may be isolated or partially isolated by geographic remoteness entailing prohibitive freights, or by political barriers such as tariffs, quotas, or exchange controls. Markets may also be effectively segregated by private cartels or unspoken understandings under which potentially competitive international firms do not challenge each other's dominance in particular export markets. In some instances markets can be made to appear larger than their natural boundaries, as where trade association adherence to a system of basing point prices keeps delivered prices high enough to enable firms to do business in localities remote from their plants. ${ }^{4}$ Such difficulties and uncertainties severely restrict the utility of "oligopoly" as a regulatory concept.

The best effort to date to translate the nebulous concept of oligopoly into specific guides for administrative action is the 1959 book by Professors Kaysen and Turner, Antitrust Policy: An Economic and Legal Analysis. ${ }^{B}$ Their criterion and classification of oligopolies are summarized in the following quotation:

A structurally oligopolistic market is one in which the few largest sellers in the market have a share of the market sufficient to make it likely that they will recognize the interaction of their own behavior and their rivals' response in determining the values of the market variables. Neither economic theory nor experience provides a definite number of firms or a size of market share they must jointly hold for this logic to apply. As our dividing point we have adopted, somewhat arbitrarily, a market share of one third of total market sales for the eight largest sellers, because in

3 On the problems of industry and business classification, see Conklin \& Goldstein, Census Principles of Industry and Product Classification, Manufacturing Industries, in NATIONAL BUREAU OF ECONOMIC RESEARCH, op. cit. supra note 2 , at 15 , and the comments which follow by Fabricant at 36, Kottke at 40, and Suits at 48.

${ }^{4}$ See FTC v. Cement Institute, 333 U.S. 683 (1948); FTC v. A. E. Staley Mfg. Co., 324 U.S. 746 (1945).

5 Cf. Nattonal Bureau of Economic Researce, op. cit. supra note 2, at 57-140, where leading economists, especially Fellner at 113, Kaysen at 116-18, and Miller at 119 , express pervasive skepticism regarding the significance of various indices of concentration.

6 This book is reviewed by Professor Ralph F. Fuchs in the book review section of this issue. 
the majority of markets with which we are familiar, a smaller number of firms with larger shares of the market generally accompany, to a significant degree, the kind of behavior indicated above. Beyond such a dividing point, the majority of markets with which we are familiar do not appear to function in this fashion.

Within the general classification of structure oligopoly we make a distinction between two subclasses. In what we call Type One structural oligopoly, the first eight firms have at least 50 percent of total market sales and the first twenty firms have at least 75 percent of total market sales. In Type One oligopoly, recognition of interdependence by the leading firms is extremely likely, and the 75 percent share of the first twenty sellers makes it likely that the response of the smaller sellers will not limit the behavior of the larger firms. Type Two structural oligopoly is defined by a market share of 33 percent for the eight largest sellers, with the rest of the market relatively unconcentrated.

The distinguishing feature of this market is the existence of an unconcentrated sector which may constitute a competitive restraint of varying significance on the concentrated firms. Empirical studies of such markets indicate no clear presumption on the importance of an unconcentrated sector in an oligopolistic market, and so this partial oligopolistic market is classified as a separate category within the general classification of concentrated markets.

The economic concept of a market is stated in terms of the behavior of buyers and sellers. Two products belong in the same market if a small change in price (or product) causes a significant diversion in a relatively short time of the buyers' purchases or the sellers' production from one product to another. ${ }^{7}$

Kaysen and Turner distinguish, in their statistics and analysis, between concentration in large industries and in small industries, on the ground that public concern is greater in the former. The study also discriminates between concentration in investment goods and input sectors of the economy, and concentration in consumer goods, because the evil effects of noncompetitive pricing at preconsumer levels are amplified at the later ones. An effort was also made to distinguish national, regional, and "heterogeneous" markets, for one or two firms might well dominate a regional market although national figures, which may be the only ones available, do not reveal high concentration in the industry. In the first appendix to this Article, a table based on the Kaysen-Turner study but omitting some of the foregoing refinements shows the "minimum" concentration which Kaysen and Turner found 
in various industries, arranged in descending order according to aggregate concentration in the largest eight firms of each industry. ${ }^{8}$

It should be emphasized that the Kaysen-Turner criterion of undue concentration-that the eight largest sellers have more than one third of the business-rests upon their judgment that "in a majority of the markets with which we are familiar" the large sellers are "likely" to recognize the interaction of their own behavior "to a significant degree." Inasmuch as the empirical basis for this judgment is not set forth, its reliability even for the United States is subject to challenge. Obviously, the judgment does not have even prima facie validity in other countries where entirely different relationships between market structure and firm behavior might be observed. But the Kaysen-Turner criterion is put forward not to condemn all concentrations above this level, but merely to identify areas in the economy where official inquiry appears to be justified. For this limited purpose, tests which are easy to apply may be satisfactory, even though the determination of the critical point on the spectrum of concentration depends largely on the subjective reactions of experienced persons. An example of such a crude index may be found in the third table appended to this Article; the table is based on the Federal Trade Commission's 1947 report on the concentration of productive facilities." The FTC considers as "extreme" concentration any situation in which the three largest companies control more than sixty per cent of the "net capital assets" in the industry. ${ }^{10}$

With this brief summary of the state of American economic thought on oligopoly, let us turn to a review of the law relating to oligopoly. It is notable, in the first place, that neither American nor typical European legislation speaks in terms of "oligopoly." This is entirely understandable in view of the lack of specific content which can be given to the term. Nor do American statutes use words like "concentration" or "dominant firm," such as are found in European law. One might even conclude from certain statements and decisions of our Supreme Court that there is a positive determination to refrain from giving legal effect to the state of concentration in an industry. "Mere size . . . is not an offense against the Sherman Act unless magnified to the point at which it amounts to a monopoly . . .,"11

8 See also the elaborate statistical analysis of concentration in the largest 4,8 , and 20 companies in each industry in Subcomm. ON ANTrTRUST AND Monopoly, Senate Comm. on the Judiciary, 85 Th Cong., 1st Sess., Report on ConcenTRATION IN AMIERICAN INDUSTRY (Comm. Print 1957).

9 FTC, op. cit. supra note 2 , at 21.

10 FTC, op. cit. supra note 2 , at 17.

11 United States v. Swift \& Co., 286 U.S. 106, 116 (1932). 
declared Mr. Justice Cardozo in 1932. And earlier, the Supreme Court had declined to order dissolution of the United States Steel Corporation although the company was the result of an illegal consolidation of numerous, huge, fully integrated steel plants into a single organization with fifty per cent of the national steel capacity. ${ }^{12}$ In United States $v$. National Lead Co., ${ }^{13}$ the Court rejected a dissolution proposal with the comment that there had been "no showing that four major competing units would be preferable to two . . . ."14 And Judge Learned Hand's famous opinion in United States v. Aluminum Co. of America ${ }^{15}$ declared that even one hundred per cent control would not necessarily violate the Sherman Act, if, for example, the defendant achieved this position without purposeful action designed to exclude others. Assuming such baneful purpose, it would still be necessary to find virtually complete and unified control of the relevant business in order to convict the defendant as a monopolist; ninety per cent of the market would be enough, but "it is doubtful whether sixty or sixty-four percent would be enough; and certainly thirty-three percent is not." 18 It would be difficult to imagine a greater contradiction than we find between this judicial declaration that the law permits one firm to control a third of the business in aluminum and the Kaysen-Turner hypothesis that a business is prima facie over-concentrated if eight firms together control a third of the business.

The divergence, however, is not as great as appears on its face. The doctrine that "size alone is not an offense" is a misleading statement of the actual position of American law, which, after all, does give significant effect to dominance and concentration. The original pronouncement of the innocence of large size was itself coupled with the qualification that "size carries with it an opportunity for abuse that is not to be ignored . . . ."17 This opens the door to something like the Kaysen-Turner proposal that special scrutiny be given to situations involving large firms-that is, to industries evidencing an unusual degree of concentration. A striking application of this principle is provided by the Alcoa case, where Judge Hand-having first performed some remarkable manipulations in market analysis to bring the com-

12 See United States v. United States Steel Corp., 251 U.S. 417 (1920).

13332 U.S. 319 (1947).

$14 I d$. at 352 .

15148 F.2d 416 (2d Cir. 1945).

$16 I d$, at 424 .

17 United States v. Swift \& Co., 286 U.S. 106, 116 (1932) ; cf. United States v. Griffith, 334 U.S. 100, 107 n.10 (1948). 
pany within range of his "monopoly" standard ${ }^{18}$-went on to scrutinize the company's behavior so rigorously as to make even its active, expansionist policy a dereliction:

Alcoa effectively anticipated and forestalled all competition. . . . It was not inevitable that it should always anticipate increases in the demand for ingot and be prepared to supply them. Nothing compelled it to keep doubling and redoubling its capacity before others entered the field. It insists that it never excluded competitors; but we can think of no more effective exclusion than progressively to embrace each new opportunity as it opened, and to face every newcomer with new capacity already geared into a great organization . . ..$^{19}$

A classic reason for opposing monopoly is that it tends to restrict supply, yet here, paradoxically, foresighted expansion of capacity is the element of behavior seized upon to put the company in violation of the law. Similarly, it is often said that the General Motors Corporation must "voluntarily" refrain from cutting prices lest it force some of its competitors out of business. Such propositions, so evidently at variance with the rationale of free competition, can be understood only as circumlocutions for an unspoken but nevertheless active concern about industry structure and concentration. We are formally committed to a law which forbids only monopolization or evil practices; and bound as we are by this formal commitment, a way-a fiction if necessary-must be found to attribute evil to giant organizations which manage to avoid our ordinary list of proscribed commercial restraints.

This attributive process may be seen operating in United States $v$. E. I. $d u$ Pont de Nemours \& Co., ${ }^{20}$ where an alleged preemption by Du Pont of General Motors' purchases of automotive finishes and fabrics was made the basis for interdicting Du Pont stock control of General Motors. It is easy to criticize the market analysis expounded by $\mathrm{Mr}$. Justice Brennan writing for the majority in that case. The dissenting Justices persuasively demonstrate that Du Pont did not actually exert control over GM purchases and that, in any event, the Clayton Act ${ }^{21}$ was not intended to apply retroactively to a purchase of stock twenty years before, when the transaction was lawful. But

18 Although Alcoa had been the sole domestic producer of virgin aluminum, its sales of that product were in competition with "secondary" aluminum, i.e., that recovered by the scrap industry. To arrive at a figure of $90 \%$ control for Alcoa, Judge Hand treated this secondary aluminum as a part of the supply controlled by the company, even though the company had sold the original material from five to twenty-five years earlier. See 148 F.2d at 422-25.

19148 F.2d at $430-31$.

20353 U.S. 586 (1957).

$21 \S 7$, as amended, 64 Stat. 1125 (1950), 15 U.S.C. $\$ 18$ (1958). 
back of the majority view was the commonsense recognition than an antitrust law which cannot prevent integration of two such financial and industrial colossi as General Motors and Du Pont would be a farce with which no Congress ever intended to entertain the American people.

The doctrine of "internal conspiracy" must also be viewed as an indirect attack on the giant firm. Under this doctrine separately incorporated units of an enterprise which is economically and functionally a single firm may be guilty of an illegal "conspiracy" when they concert their price and other policies. ${ }^{22}$ I have not seen this doctrine applied to any but very large organizations.

As might be expected, a legal policy against concentration which can be given effect only indirectly and through fictions is likely to operate erratically. In some sectors of American antitrust law the judges have evolved rules dealing more explicitly with dominance and oligopoly. Thus, in interpreting section 3 of the Clayton Act which forbids exclusive dealing arrangements "where the effect may be to substantially lessen competition," 23 the defendant's leading position in its market and the adherence of major competitors to parallel policies have become crucial factors. In Standard Oil Co. v. United States, ${ }^{24}$ the defendant's exclusive dealing contracts were held illegal where it appeared that defendant was the largest seller in its region-controlling twenty-three per cent of the sales-and that all other "major suppliers" followed similar practices, thus "collectively, even though not collusively, preventing a late arrival from wresting away more than an insignificant portion of the market." 25

22 Kiefer-Stewart Co. v. Joseph E. Seagram \& Sons, Inc., 340 U.S. 211 (1951) ; cf. Distillers Corp.-Seagrams, Ltd., 50 F.T.C. 738 (1954) (subsidiaries and parent ordered not to collaborate in pricing). But cf. United States v. Arkansas Fuel Oil Corp., Trade Reg. Rep. (1960 Trade Cas.) গ 69619, at 76496 (D.C. Okla. 1960), where discussion of a price increase with an officer of one's parent corporation was held to be "mere approval by a parent corporation... [which] does not constitute a per se violation of the Sherman Act." See the discussion of this case in text following note 38 infra. See also Schwartz, Relations veith Affiliated Customers, in N.Y. STATE Bar Ass'N Sectron on ANTITRUST LAw, ANTITRUST LAw SyMPOSIUM 214 (1952); Note, Intra-Enterprise Conspiracy under the Sherman Act, 63 Y ALE L.J. 372 (1954).

2338 Stat. 731 (1914), 15 U.S.C. § 14 (1958).

24337 U.S. 293 (1949).

25 Id. at 309. See Dictograph Prods., Inc. v. FTC, 217 F.2d 821, 827 (2d Cir. 1954), where it was said in interpretation of the Standard Oil case: "Where the alleged violator dominated or was a leader in the industry, proof of such fact was, at an early stage, determined to be a sufficient predicate from which to conclude that the use of exclusive-dealing contracts was violative of Section 3 and other factors appear to have been largely ignored. . . . More recently, the Supreme Cotirt extended the rule to business organizations enjoying a powerful, though clearly not dominant position . . . "Cf. Schwartz, Potential Impairment of CompetitionThe Impact of Standard Oil Co. of Califormia v. United States on the Standard of Legality Under the Clayton Act, 98 U. PA. L. Rev. 10 (1949). 
In recent years American merger law has given evidence of special sensitivity to the acquisition of lesser companies by leading firms, even when the resulting combinations do not approach the minimum level of concentration which Judge Hand deemed necessary to constitute a monopoly. ${ }^{26}$ But, in contrast to the exclusive dealing cases, there seems to be no tendency to make market dominance or leadership a sufficient circumstance, standing alone, to establish a violation or prima facie violation of the merger provisions of section 7 of the Clayton Act. ${ }^{27}$ The size of firms involved and the structure of the industry are merely circumstances to be considered with many others in determining whether the merger will probably impair competition "substantially."

Although oligopolistic structure appears to be significant in varying degrees with respect to exclusive dealing and mergers, it receives almost no recognition in our laws dealing with price discrimination-and this despite the fact that the relevant language of section 2 of the Clayton Act, $^{28}$ as amended by the Robinson-Patman Antidiscrimination Act, ${ }^{28}$ is parallel to that of sections 3 and 7. A dominant petroleum firm may justify discrimination among its customers on the ground that it is meeting a competitive offer. ${ }^{30}$ A manufacturer producing upwards of sixty per cent of burner controls may justify price differentials by showing that the disadvantaged customers were nevertheless thriving, and that therefore competition was not being impaired. ${ }^{31}$

Still another way in which American antitrust law has adapted itself to the phenomenon of oligopoly is by the doctrine of "conspiracy" based on "conscious parallel action." Firms which persistently follow parallel business policies will be treated as if they had agreed upon those

20 See, e.g., American Crystal Sugar Co. v. Cuban-American Sugar Co., 259 F.2d 524 (2d Cir. 1958) (combination would be fourth largest in country, supplying $13 \%$ of sugar in its region); United States v. Brown Shoe Co., 179 F. Supp. 721 (E.D. Mo. 1959), prob. juris. noted, 363 U.S. 825 (1960) (fourth largest shoe producer having $5 \%$ of total production combining with another firm having $0.5 \%$ of total production and $1.2 \%$ of total retail shoe sales, the latter attribute making it the largest family shoe chain retailer); United States v. Bethlehem Steel Corp., 168 F. Supp. 576 (S.D.N.Y. 1958) (combination of second and sixth largest steel firms); Hamilton Watch Co. v. Benrus Watch Co., 114 F. Supp. 307 (D. Conn.), aff'd, 206 F.2d 738 (2d Cir. 1953) (combination controlling $20 \%$ of nationally advertised jeweled watches).

27 For a criticism of the FTC's failure-notwithstanding the parallel language of $\$ \S 3$ and 7 -to conform merger law to exclusive dealing law in this respect, see Staff of Subcomm. No. 5, House Comar. on the Judiciary, 84th Cong., 1st Sess., Interim Report on Corporate and Bank Mergers 19-25 (Comm. Print 1955).

2838 Stat. 730 (1914), 15 U.S.C. $\$ \S 13$ (a), (b) (1958).

2049 Stat. 1528 (1936), 15 U.S.C. $\$ 13 a$ (1958).

30 Standard Oil Co. v. FTC, 340 U.S. 231 (1951). Perhaps the disapproval of "systematic" discrimination, allegedly to meet competition, operates with special force against oligopolies. See FTC v. Cement Institute, 333 U.S. 683 (1948) ; FTC v. A. E. Staley Mfg. Co., 324 U.S. 746 (1945); Moog Indus., Inc. v. FTC, 238 F.2d 43 (8th Cir. 1956), aff'd per curiam, 355 U.S. 411 (1958).

31 Minneapolis-Honeywell Regulator Co. v. FTC, 191 F.2d 786 (7th Cir. 1951), petition for cert. dismissed, 344 U.S. 206 (1952). 
policies, at least where there is some evidence that they consciously faced the policy issue as a common problem. ${ }^{32}$ On the other hand, the inference of conspiracy from parallel action can be rebutted by showing that identical commercial conditions facing the separate firms compelled them to act identically. ${ }^{33}$

Closely related to the doctrine of conspiracy based on conscious parallel action is the proposal to make "price leadership" presumptive evidence of conspiracy between the price leader and his followers. ${ }^{34}$ In American Tobacco Co. $v$. United States, ${ }^{35}$ the three largest cigarette companies were convicted of jointly monopolizing the cigarette business by employing, in common, certain buying practices allegedly designed to prevent the manufacture of cheaper cigarettes and by slavishly imitating each other's price moves in the distribution of cigarettes. The companies' insistence that identity of price movement was compelled by competition rather than a manifestation of monopoly was rendered somewhat ridiculous when the president of the American Tobacco Company testified that not only was he compelled to reduce his price whenever his rivals announced a reduction, lest he lose sales, but also that he was compelled to increase prices when Reynolds raised theirs, since otherwise Reynolds' increased profits would enable them to spend more money on advertising and so again deprive him of sales. ${ }^{36}$ Absurd as this seems, economists would probably support the proposition that oligopolists in this situation have no alternative but to arrive, with or without agreement, at a common price, and that it will be a high price in relation to cost. Indeed, a study of the sequel to the Tobacco case revealed that the companies followed essentially the same price policies after the case as they did before, and increased their combined share of the national market from sixty-eight per cent to seventy-six per cent. ${ }^{37}$ The unreliability of the parallel action and price leadership approach to

32 Interstate Circuit, Inc. v. United States, 306 U.S. 208 (1939) (common terms of licensing second-run showings of films of dominant movie producers); Milgram v. Loew's, Inc., 192 F.2d 579 (3d Cir. 1951), cert. denied, 343 U.S. 206 (1952) (denying first-run showings to drive-in theaters). See Givens, Parallel Business Conduct Under the Sherman Act, 5 Antrtrust Buli. 273 (1960); Note, Conscious Parallelism -Fact or Fancy?, 3 Stan. L. Rev. 679 (1951).

33 Pevely Dairy Co. v. United States, 178 F.2d 363 (8th Cir. 1949), cert. denied, 339 U.S. 942 (1950) (identical pricing by "competing" milk companies explicable by uniform federally regulated price paid to farmers for raw milk, uniform wages paid to workers represented by single union, standardized product, and production conditions regulated by health ordinances).

34 Handler, A Study of the Construction and Enforcenent of the Federal ANTITRUST LAws 44 (TNEC Monograph No. 38, 1941).

35328 U.S. 781 (1946).

36 Id. at 805.

37 Nicholls, Price Polictes in the Cigarette Industry 402 (1951). 
oligopoly is illustrated by a recent case ${ }^{38}$ in which defendant oil companies were acquitted of charges that they unlawfully conspired to fix and raise prices following the Suez crisis. Two of the companies had raised their prices on the same day and others followed promptly. But the court found that the closing of the Suez Canal and certain cost increases prior to the price increase constituted "economic justification" sufficient to prevent the evidence of an "agreement" from rising above the level of suspicion.

One trouble with inferring or presuming conspiracy from parallel action is that it seems to lead logically to remedial action directed against the presumed conspiracy. It assumes that if the parties are compelled to act "independently" they will behave differently. But we know that in a sufficiently concentrated oligopoly the distinction between independent and concerted action tends to evaporate. ${ }^{39}$ The theoretical error in diagnosing the problem as one of conspiracy rather than of structure is accompanied by a practical problem of devising effective controls. One can hardly order the "leader" to stop setting and publicizing its own prices. It would be equally difficult and unfair to enjoin "followers" from charging as much as their big leader-and they obviously cannot charge more.

A final illustration of the equivocal and ineffective response of American law to the problem of oligopoly and parallel pricing is provided by the so-called fair trade laws which authorize suppliers to set resale prices. These laws reinforce the tendency of concentrated industries to operate on the basis of parallel high pricing by the large firms. They do this by eliminating an important source of pressure for independent, competitive, downward price adjustments at the producer level-namely, pressure by retailers whose profit margin has been cut by the competition of other retailers. It has often been observed, for example, that gasoline "price wars" at the retail level precipitate competitive wholesale price reductions, which the supplier is compelled to make in order to enable his distributor to maintain his gallonage. "Fair trade" helps, therefore, to reduce the number of entrepreneurs whose decisions must be aligned in order to stabilize prices. In cigarettes, toothpaste, liquor, and consumer durables, the number of price makers is reduced by fair trade to fewer than a half-dozen giant producers. Inasmuch as these producers have already succeeded in par-

38 United States v. Arkansas Fuel Oil Corp., Trade REg. Rep. (1960 Trade Cas.) \ 69619 (D. Okla. 1960).

39 See Att'y Gen. Nat' Comm. Antitrust Rep. 326 (1955): "When sellers are few, even in the absence of conspiracy, the market itself may not show many of the characteristics of effective competition, and in fact may not be effectively competitive in the economic sense." 
tially insulating their products from competition with each other by heavy advertising expenditures designed to persuade the consumer that each trademark identifies a unique product, the insistence of the fair trade laws that products be in "free and open competition with products of the same general class" is rendered ineffective. ${ }^{40}$

In sum, the failure of American legislation to deal explicitly with the problem of oligopoly has not wholly prevented the judicial development of legal answers to oligopoly but has made that development inconsistent and unpredictable. Even legislation especially designed to slow up the process of economic concentration, like recent antimerger laws, has fallen short of its goal because of the failure of antitrust proponents to face up directly to the problem of oligopoly. These antimerger laws may actually aggravate the evils at which they were aimed, because only future mergers are affected. The great combines in steel, motors, and banking have their dominance confirmed by antimerger acts which inhibit the amalgamation of smaller units but fail to provide for dissolution of the very amalgamations whose formation stimulated enactment of the laws. This has been the history of the Clayton Act and its amendments as well as of recent legislation ${ }^{41}$ against holding company expansion in the fields of banking and savings and loan associations. Only in the field of public utility holding companies did the Roosevelt administration succeed in pushing through a divestiture program to confine each enterprise to "a single integrated public-utility system" or, with special approval, contiguous systems where the combined operation "is not so large . . . as to impair the advantages of localized management, efficient operation, or the effectiveness of regulation." ${ }^{42}$

It remains to examine cognate aspects of certain European legislation. It is noteworthy, in the first place, that Europe has faced the problem of oligopoly squarely and explicitly, without resort to fictions of evil intent, strained constructions of conspiracy, or bizarre findings of anticompetitive activity in plant expansion or price-cutting. The British Monopolies and Restrictive Practices (Inquiry and Control) Act of $1948^{43}$ was made applicable to situations where a third or more

${ }^{40}$ Cf. Eastman Kodak Co. v. Home Util. Co., 138 F. Supp. 670, 677 (D. Md.), aff'd in part, modified in part, remanded, 234 F.2d 766 (4th Cir. 1956) (manufacturer's fair-traded product in free and open competition with others in its class despite substantially complete fair trade coverage of all similar products).

41 Bank Holding Company Act, 70 Stat. 133 (1956), 12 U.S.C. $\$ \$ 1841-48$ (1958), 26 U.S.C. $\$ \S 1101-03$ (1958) ; 73 Stat. 691 (1959), 12 U.S.C. $\S 1730$ (a) (Supp. 1959) (saving and loan holding companies).

42 Public Utility Holding Companies Act of 1935, $\$ 11(b)(1), 49$ Stat. 820, 15 U.S.C. $\$ 79 \mathrm{k}(1958)$.

$4311 \& 12$ Geo. 6 , c. 66 . 
of the market is supplied either by one person or "[by] two or more persons who, whether voluntarily or not, and whether by agreement or arrangement or not, so conduct their respective affairs as in any way to prevent or restrict competition ...." 44 So also, section 22 of the 1957 German Act Against Restraint of Competition defines "a marketdominating enterprise" as one which is not subject to substantial competition or two or more enterprises insofar as there is, either in general or specific markets, no substantial competition in fact between them, ${ }^{\mathbf{4 5}}$ if collectively they are not subject to substantial competition by other firms. Sections 23 and 24 of the act ${ }^{46}$ give further specificity to the concept of dominating enterprise by requiring report to the Cartel Authority of any merger where the resulting combine would have as much as twenty per cent of the market. The Cartel Authority investigates the likelihood that the combine will obtain market dominance in the section 22 sense. And article 24 of the Economic Competition Act of the Netherlands takes cognizance of situations where "a dominant position [of economic power] exists whose consequences conflict with the general interest." 47 "Dominant position" is defined in section 1 as "a de facto or de jure relationship in trade or industry which entails a predominant influence by one or more owners of enterprises on a market for commodities or services in the Netherlands." 48 The treaties establishing the new economic communities of Europe likewise contain special provisions for "enterprises which, in law or in fact, have or acquire . . . a dominant position which protects them from effective competition . . . . 49

Once it has been determined that the firms in an industry "in fact" conduct themselves in a noncompetitive fashion, they become subject, under typical European "antitrust" legislation, to a degree of government control of business decision, including even price controls. The

44 Monopolies and Restrictive Practices (Inquiry and Control) Act, 1948, 11 \& 12 Geo. 6, c. 66, $\$ \$ 3(2)$ (supply of goods), 4(2) (processing of goods); cf. $\$ 5$, which in relation to exports required "agreements or arrangements, whether legally enforceable or not."

45 Act of July 27, 1957, translated and reprinted in 1 Gume to Legislation on Restrictive Business Practices, pt. $D$ at 13 (European Productivity Agency of the Organization for European Economic Cooperation 1960) [hereinafter cited as $R_{E}$ Strictive Practices Legislation].

46 Act of July 27, 1957, translated and reprinted in 1 Restrictive Practices LegisLation, pt. D at 14.

47 Act of June 28, 1956, as amended, Act of July 16, 1958, translated and reprinted in 2 Restrictive Practices Iegislation, pt. NL at 10.

48 Act of June 28,1956 , as amended, Act of July 16, 1958, translated and reprinted in 2 Restrictive Practices Legislation, pt. NL at 1.

49 Treaty Establishing the European Coal and Steel Community, April 18, 1951, art. 66(7), in ROyal INSTITUTE OF INT'L AFFaIRs, Documents ON INTERNATIONAL AfFaIRs 1951, at 173 (1954); of. Treaty Establishing the European Economic Community, March 25, 1957, art. 86, in 51 AM. J. INT'L L. 865 (1957). 
British Monopolies Commission's Report on the Supply of Dental Goods found that the Amalgamated Dental Company and its affiliates were "not . . . a monopoly in the ordinary sense," s0 but recommended that the group should "reduce the prices of . . . porcelain teeth." 51 While the Monopolies Commission's recommendations do not have the force of law, a recent account in the London Economist concerning a Commission report on the fertilizer industry notes that Imperial Chemical Industries, Ltd., was induced to submit to "voluntary price control." 52 In Germany market-dominating enterprises may be required to desist from "misuse" of their market position in pricing or in terms or conditions of sale..$^{53}$ "Misuse" does not imply any subjective evil purpose or knowledge that the conduct amounts to misuse. ${ }^{54}$ In Holland firms in "a dominant position" may have their prices and terms of sale regulated even to the point of a requirement that goods or services be supplied "at the customary cash price on the market concerned." 55 And the High Authority of the European Coal and Steel Community is authorized to fix the prices, conditions of sale, manufacturing and delivery schedules of dominant firms, where this becomes necessary "to prevent use of such position for purposes contrary to [the Coal and Steel Treaty]." 50 The purposes of the Treaty, listed in articles 2 and 3 , include expanding production, prevention of discrimination, and the securing of "the lowest prices which are possible" without shifting cost burdens unfairly.

Nothing could be further from American antitrust ideology than the idea of official intervention in pricing and other economic decisions of entrepreneurs where no malpractice or evil intent appears. Yet, just as we have arrived by indirection at a rough policy relating to oligopoly

50 Monopolies and Restrictive Practices Comm'n, Report on the Supply of Dental Goods 67 (1950).

61 Id. at 69. On the Monopolies Commission's tolerant view of concerted pricing, see Grunfeld \& Yamey, United Kingdom, in ANTITrust Laws-A Comparative Symposium 340, 382 (Friedmann ed. 1956); cf. In re Water-Tube Boilermakers' Agreement, L.R. 1 R.P. 285 (1959), 108 U. PA. L. ReV. 924 (1960) (application of the "rule of reason" to price agreements under the Restrictive Trade Practices Act of 1956).

52194 The Economist 741 (1960). The report itself was not available to the writer when this Article was prepared.

53 Law Against Restraint of Competition $\$ 22(3)$, Law of July 27, 1957, translated and reprinted in 1 Restrictive Practices Legislation, pt. D at 13, 14 .'

54 Bartholomeyczik, Market Dominating Practices, in MüLLER-HeNnEBERGSCHWARTZ, GESETZ GEGEN WETTBEWERBSBESCERÄNKUNGEN 468, 529 (1958).

55 Economic Competition Act $\$ 24$, Act of June 28, 1956, as amended, Act of July 16, 1958, translated and reprinted in 2 Restrictrve Practices Legislation, pt. NL at 10 .

56 Treaty Establishing the European Coal and Steel Community, April 18, 1951, art. 66(7), in ROYAL INSTITUTE of INT'L AFFaIRs, Documents oN INTERNATIONAL Afratrs 1951, at 173 (1954). 
and parallel action (although our statutes do not speak in these terms), so we are beginning to impose upon powerful corporations affirmative obligations not unlike those expressly provided for in advanced European legislation. Thus, a giant integrated aluminum company may be required to maintain a margin between the price at which it sells sheet aluminum and the price at which it sells fabricated products sufficient to permit independent fabricators to survive. ${ }^{57}$ The officials of a mammoth broadcasting network, which owns TV stations and at the same time provides network programs on a contract basis to hundreds of affiliated stations, have avowed that whenever the network proposes to buy an affiliated station it pays the first price asked by the owner. ${ }^{58}$ This appears to be a recognition that its economic position, based on the power to discontinue the vital affiliation, is so overwhelming that the network stands in jeopardy under the antitrust laws if it tries to bargain for a lower purchase price. The dominant position of the Eastman Kodak Company in production of color film led to an antitrust decree requiring it to desist from including a processing charge in the price of film so that film users would be free to patronize independent processors. ${ }^{59}$ The right of large firms to select their customers-for example, to refrain from dealing with distributors who cut resale prices-has been under attack in Congress and has been whittled down in recent Supreme Court decisions. ${ }^{60}$

On the other hand, there are notable cases where American tribunals have failed to intervene effectively to control the exercise of oligopoly power. Thus, the General Electric Company was permitted to dictate the price at which retailers sold its electric lamps, as well as the price of electric lamps manufactured and sold by its giant competitorlicensee, Westinghouse, ${ }^{61}$ although the Court might well have drawn a distinction between the right of small patentees to include price-fixing clauses in patent licenses and the right of industrial giants to dominate a market through contractual arrangements based on patents. The General Electric case has never been directly overruled, although its N.Y.).

57 United States v. Aluminum Co. of America, 1954 Trade Cas. $\llbracket 67745$ (S.D.

58 Brief for Appellants, pp. 23-24, Poller v. Columbia Broadcasting Sys., appeal docketed, No. 15379, D.C. Cir., Sept. 25, 1959 (quoting depositions). For an illustration of the allegedly coercive use of network broadcasting power, see United States v. Radio Corp of America, 358 U.S. 334 (1959).

58 United States v. Eastman Kodak Co., 1954 Trade Cas. \67920 (W.D.N.Y.).

${ }^{60}$ See United States v. Parke, Davis \& Co., 362 U.S. 29 (1960) ; Staff of Senate Select Comm. on Sriall Business, 86th Cong., 1st Sess., Tre Rrght to BuY (Comm. Print 1959). See also A. C. Becken Co. v. Gemex Corp., 272 F.2d 1 (7th Cir. 1959); United States v. United Shoe Mach. Corp., 110 F. Supp. 295 (D. Mass. 1953), aff'd per curiam, 347 U.S. 521 (1954).

61 United States v. General Elec. Co., 272 U.S. 476 (1926); United States v. General Elec. Co., 82 F. Supp. 753, 817-27 (D.N.J. 1949). 
authority is much shaken by later decisions which do give effect to oligopoly considerations. ${ }^{62}$

The leading case of Associated Press $v$. United States ${ }^{63}$ presented in reality a problem in oligopoly control of national and international news, for such news was available from only three agencies of which AP was by far the most powerful. Yet, the matter was disposed of on the narrow basis of a "conspiracy" among the newspaper members of AP to "discriminate" against competitors of existing members in passing on the competitors' applications to join AP. Accordingly, although AP was convicted of violating the Sherman Act, the Court's order went no further than to prohibit the discrimination, leaving undisturbed AP's exclusive right to distribute news originating with its powerful membership and its exclusive arrangements with foreign news syndicates. It is not surprising that the number of American news syndicates was soon reduced to two. ${ }^{84}$

The uneasy and inadequate use of the antitrust laws to impose affirmative controls on oligopoly has led to a variety of proposals to change and supplement the law. Some seek to inaugurate a program of deconcentration. Kaysen and Turner, for example, call for a declaration that "an unreasonable degree of market power as such [is] illegal." ${ }^{65}$ They propose that, in passing upon the legality of mergers, a twenty per cent share of a market be considered prima facie excessive concentration. $^{86}$ "Market power shall be conclusively presumed where, for five years or more, one company has accounted for 50 percent or more of annual sales in the market, or four or fewer companies have accounted for 80 percent of such sales." ${ }^{\text {e7 }}$ Although endorsing divestiture and dissolution as remedies, they provide a number of defenses under which considerable concentration could be justified as reasonable -for example, where concentration is necessary to achieve economies

62 United States v. New Wrinkle, Inc., 342 U.S. 371 (1952); United States v. Line Material Co., 333 U.S. 287 (1948) (four Justices favored overruling General Electric); United States v. Masonite Corp., 316 U.S. 265 (1942); Newburgh Moire Co. v. Superior Moire Co., 237 F.2d 283 (3d Cir. 1956) (price alignment of three-fifths of industry invalidates licensing agreement).

63326 U.S. 1 (1945).

64 See 1958-1 Trade REg. Rep. đ 4207.105, reporting Department of Justice approval of the merger of United Press and International News Service, the latter being in "failing circumstances." $C f$. Times-Picayune Publishing Co. v. United States, 345 U.S. 594 (1953), where it was held that a newspaper publisher with half the readership and $40 \%$ of the advertising in New Orleans was not so "dominant" as to require it to desist from using the "unit rule" in the sale of advertising. Under this rule an advertiser who wished space in the publisher's morning paper had to buy space also in his afternoon paper. The competing afternoon paper soon expired. See Death of the Times-Star, Time, Aug. 4, 1958, p. 47.

65 Kaysen \& Turner, Antitrust Policy: An Economic and Legal Analysis 111 (1959).

66 Id. at 99, 133; cf. Stigler, Mergers and Preventive Antitrust Policy, 104 U. PA.

L. REv. 176, 182 (1955).

67 KAYSEN \& TURNER, op. cit. supra note 65 , at 98. 
of scale, or dissolution of a firm concentrated in a single plant is not physically practicable.

I have a mild preference for supplementing section 2 of the Sherman Act with a legislative program that differs somewhat from the Kaysen-Turner proposal. I would begin with a narrower class of enterprises. A firm would be subject to reorganization if: (1) it has assets in excess of one billion dollars; (2) it operates in a basic industry; and (3) it has twenty per cent of the national market or is one of the four leading firms which in the aggregate have fifty per cent of the market. The statute would specify the industries which the legislature deems basic-for instance, steel and automobiles.

There is nothing magical about the requirement of assets in excess of one billion dollars. I am less concerned with the precise figure than with indicating the principle of the legislation. ${ }^{88}$ The figure might be a half billion, either generally or in selected industries which Congress might designate on the basis of past antitrust experience. In determining a firm's assets, it would be necessary to have rules declaring what affiliations between separately incorporated firms should cause them to be treated as a single enterprise.

The firms thus singled out should be reorganized under a criterion stiffer than the Kaysen-Turner standard of "unreasonable market power." The test should be whether they are larger than can be justified by economies of scale in production and distribution, with the burden of proof placed on the firm; that is, if a firm falls within the standards I have formulated, it must prove that its size leads to lower costs of production or distribution, or it will be reorganized into smaller business units.

This proposal places no absolute limit on size of firm, but merely institutes inquiry where industrial giants operate in overly concentrated basic industries. Firms of more than a billion dollars in assets would be left untouched if such size is shown to be economical. A superbillion firm, which is not dominant in a basic industry, is left free to expand in fields dominated by other giants, thus encouraging these powerful units to invade each other's markets.

The proposed billion-dollar figure is not an imputation of evil beginning at that level, but only a device to limit the initial administrative effort to a reasonable number of cases where economic power has most obviously gone very far. Experience with these firms should equip the regulatory agency to expand controls if that should prove desirable. Naming a figure like one billion dollars will also enable

68 However, note the discussion of Kaysen and Turner's reasons for rejecting any such limitation in Professor Fuchs' book review appearing in the book review section of this issue. 
management and counsel to plan a firm's development with an eye to the law's requirements. Thus, as the critical size is approached, consideration may be given to voluntary divestiture of peripheral activities, by "spinning off" or other arrangements. Or expansion can be directed into areas where the firm will not be one of the dominant oligopolists.

The deconcentration program I envision would be carried out by an administrative agency, presumably the Federal Trade Commission, in civil proceedings. The criminal and treble-damage provisions of the Sherman ${ }^{69}$ and Clayton ${ }^{70}$ Acts are inappropriate to cases of this character involving no imputations of misbehavior or illicit monopolistic intent. ${ }^{71}$ Initially, at least, the program would be confined to the manufacturing and mining industries, in view of the special considerations applicable to regulated transportation businesses and public utilities. Insurance and banking, where some of the very largest firms are found, ${ }^{72}$ present some unique problems as to both the efficacy of present regulation and the measurement of concentration, so that further inquiry may be needed before assigning responsibility for a deconcentration program in these fields.

To restrain the power of very large organizations that would remain in existence under any conceivable decentralization program, there is need for a statutory declaration that exclusive dealing, mergers, price discrimination, restrictive patent licensing, and other anticompetitive practices are illegal when engaged in by dominant or leading firms, although smaller firms might be able to justify the same practices as reasonable or involving only minimal effect on competition. ${ }^{73}$

Such proposals, however strongly they may be resisted in the United States, remain in the mainstream of antitrust tradition, strengthening the proscriptions against concentration of economic power and unfair practices. In quite a different tradition are pending proposals to subject price increases in major concentrated industries to a preaudit by an administrative agency or legislative committee. ${ }^{74}$

69 Ch. 647, §7, 26 Stat. 210 (1890).

$70 \S 4,38$ Stat. 731,15 U.S.C. \$ 15 (1958).

71 Professor Fuchs reaches this same conclusion in his review of Kaysen and Turner's book in the book review section of this issue.

${ }^{2}$ E.g., Metropolitan Life Ins. Co. (over $\$ 15$ billion in assets) ; Bank of America (over $\$ 10$ billion in assets).

73 See Atr'y Gen. NAT'L Comm. Antitrust Rep. 392 (1955) (dissent of L. B. Schwartz).

74 See S. 1237, 86th Cong., 1st Sess. (1959), which would, if enacted, amend the Employment Act of 1946, 60 Stat. 23, 15 U.S.C. $\$ \$ 1021-24$ (1958), to read in part: "It shall be the duty and function of the [Council of Economic Advisers] to hold public hearings concerning (a) price increases, proposed in industries where most of the output.is produced by relatively few firms, which increases appear to threaten economic stability ...." 
Such a measure was suggested by Professor Galbraith in the course of Senator Kefauver's hearings on administered prices. ${ }^{75}$ These hearings disclosed, for example, that the steel companies did not offer each other rivalry in pricing but, on the contrary, were able through the price leadership of the United States Steel Corporation to raise prices more quickly than costs increased, even in a declining market-a classic example of oligopolistic parallel pricing.

The pending price-notification bill ${ }^{76}$ falls somewhere between the British Monopolies Commission postaudit of oligopoly pricing, which leads to "voluntary" price reductions, and the strong Dutch provisions for regulated pricing and production. I wish that I could be more hopeful that the bill would make an effective contribution to solution of the problem of parallel pricing by dominant firms. It seems more likely to set up a perpetual and inconclusive political debate. But if the government, having exhausted its best efforts to maintain workable competition, must inquire into pricing, it seems obvious that continuous administrative supervision is essential and that the mission of an agency charged with such supervision should be clearly and narrowly defined. It should be directed to concern itself primarily with large, basic, and highly concentrated industries, to report regularly to the legislature on such matters as costs, profits, and freedom of entry, and to make recommendations on reorganization, taxation (to recapture excess profits), tariff policy (to dilute the oligopoly by encouraging foreign competition), and procurement (so that government purchasing does not reinforce oligopoly). The very prospect of this kind of supervision and publicity would do much to induce moderation in the exercise of oligopoly power, while the information obtained would lay the basis for the continuous evolution of rational legal control of over-concentrated industries.

Although the price-notification bill has its difficulties and breaks with the antitrust tradition, it contains an idea that may be seminal for the future development of antitrust law. It suggests that the signal for governmental concern and the starting point of official inquiry should be how the prices of important products are actually behaving. If they are rigid, or move in disregard of costs, or are set at levels that discourage a desirable expansion of demand, may we not move from that observation directly to an appropriate official response without going through the intermediate steps of determining the "boundaries" of a

75 See Subcomm. on Antitrust and Monopoly of the Senate Comm. on the Judiciary, Report on Adninistered Prices in the Steel Industry, S. REP. No. 1387, 85th Cong., 2d Sess. (1958); Schwartz, Administered Prices, Oligopoly and the Sherman Act, in 12 ABA Antitrust Section Rep. 17 (1958).

76 S. 1237, 86th Cong., 1st Sess. (1959). 
"market," making the difficult measurement of "concentration" in the market, and adopting some controversial criterion of excessive concentration? ${ }^{77}$ It will be recalled that Kaysen and Turner arrive at their criterion of dangerous degree of concentration by observing that most markets concentrated to that degree are "likely" to behave oligopolistically "to a significant degree." If economists can recognize oligopolistic, antisocial pricing, a law of the future may well provide that appropriate counter-measures be taken, including but not by any means limited to reorganizing the leading firms.

$7 \pi$ Compare the complete integration of "antitrust" regulation into a general regime of price regulation in Norway. The Norwegian authorities, looking primarily at price behavior rather than at structure, may even encourage consolidations, agreements to curtail price competition, or group boycotts of foreign firms, where they believe such action is beneficial to the public interest. See Eckhoff, Norway, in ANtitrust Laws-A Comparative Symposium 281, 298-305 (Friedmann ed. 1956). 


\section{APPENDIX I}

High Concentration in American Manufacturing Industries *

Value of Shipments
(thousands
of dollars) $\dagger$

Minimum
Concentration Ratio
First First
8 Firms $\$ 20$ Firms

Primary lead

$(305,000)$

Primary copper $\ldots \ldots \ldots \ldots \ldots \ldots \ldots . . . . . . .$.

$(490,000)$

Flat glass

499,267

$\begin{array}{lr}\text { Primary aluminum } \ldots \ldots \ldots \ldots \ldots \ldots \ldots \ldots . . & 464,754 \\ \text { Typewriters } \ldots \ldots \ldots \ldots \ldots \ldots \ldots \ldots . & 141,677\end{array}$

$100(6)$

159,679

Hard-surface floor coverings ..........

365,169

309,650

Electric lamps (bulbs) $\ldots \ldots \ldots \ldots \ldots \ldots$

$1,202,343$

775,469

426,197

153,524

71,636

Salt

$1,621,917$

$\begin{array}{lr}\text { Corn wet milling products } \ldots \ldots \ldots \ldots . . & 435,966 \\ \text { Cereal breakfast foods ............... } & 330,970\end{array}$

$\begin{array}{lr}\text { Corn wet milling products } \ldots \ldots \ldots \ldots . . & 435,966 \\ \text { Cereal breakfast foods ............... } & 330,970\end{array}$

Tin cans and other tinware .......... 1,340,605

Sewing machines ................ 107,492

Aluminum rolling and drawing ....... 760,416

Primary nonferrous metals, n.e.c. ..... 396,004

Transformers $\ldots \ldots \ldots \ldots \ldots \ldots \ldots \ldots \ldots .628,917$

Computing and related machines ...... 501,311

Tractors $\ldots . \ldots \ldots \ldots \ldots \ldots \ldots \ldots \ldots . \quad 1,070,836$

Primary zinc .................. 205,039

Compressed and liquified gases ........ 195,390

$\begin{array}{rr}100(6) & - \\ 100(9) & - \\ 99 & 100 \\ 99 & 100 \\ 98 & 99 \\ 97 & 100 \\ 97 & 99 \\ 96 & 99 \\ 95 & 99 \\ 94 & 97 \\ 94 & 99 \\ 93 & 99 \\ 93 & 99 \\ 91 & 99 \\ 90 & 97 \\ 89 & 98 \\ 89 & 96 \\ 89 & 95 \\ 87 & 93 \\ 86 & 95 \\ 86 & 93 \\ 84 & 96 \\ 84 & 94 \\ 83 & 99 \\ 83 & 90\end{array}$

The remaining Kaysen and Turner data may be summarized as follows:

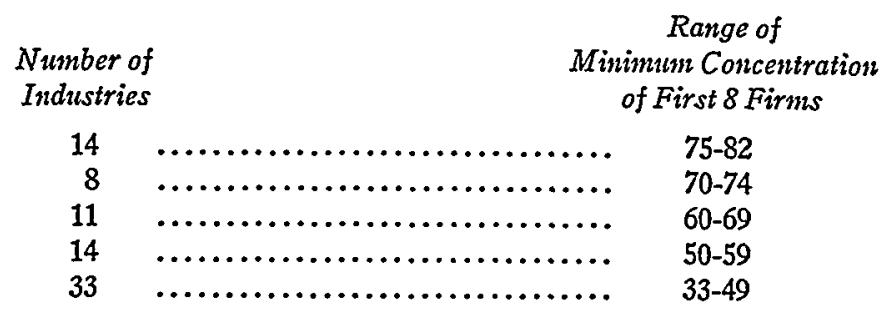

* Based on Kaysen \& Turner, Antitrust Polycy: An Economitc and Legai ANALYsis 275-80 (1959).

$\dagger$ Values of shipments stated within parentheses are estimated.

$¥$ Where impossible to compute the concentration ratio for eight firms, the number of firms used is given parenthetically. 


\section{APPENDIX II}

Degree of Concentration in Largest Americain Manufacturing Industries *

Value of Shipments
(thousands
of dollars) $\dagger$

Minimum
Concentration Ratio
First $\quad$ First
8 Firms $\quad 20$ Firms $\ddagger$

Meat products $\ldots \ldots \ldots \ldots \ldots \ldots \ldots \ldots \ldots$
Blast furnaces, steel works, and rolling mills.....................

Aircraft and aircraft equipment.......

Motor vehicles and parts ............

Misc. food and kindred products .......

Aircraft engines and propellors .......

Organic chemicals, n.e.c. ............

Cigarettes and tobacco...$\ldots \ldots \ldots \ldots$

Malt and malt liquors ..............

Misc. rubber products ..............

Pharmaceutical preparations .........

Insulated wire and cable $\ldots \ldots \ldots \ldots$.

Tires and inner tubes...$\ldots \ldots \ldots \ldots$

$12,682,723$

$(9,400,000)$

$8,412,520$

$(6,620,000)$

$3,700,349$

$3,381,551$

$3,231,191$

$2,816,216$

$2,047,945$

$1,956,694$

$1,946,672$

$1,772,935$

$1,621,917$

$1,599,859$

Soap, glycerin, cleaning and polishing preparations, and related products ..

Radios and related products .........

Paints, varnishes, and allied products ..

Plastic materials

Refrigeration equipment ............

Periodicals .......................

Tin cans and other tinware...$\ldots \ldots$

Motors and generators..........

Coke and by-products ..............

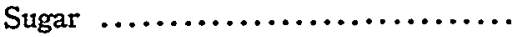

Synthetic fibers

Copper rolling and drawing ..........

Tractors

Farm machinery (except tractors) ...

Electric control apparatus

$\begin{array}{ccl}1,590,527 & 52 & 66(28) \\ (1,530,000) & 35 & 54 \\ 1,503,728 & 36 & 48 \\ 1,463,460 & 61 & 78 \\ (1,400,000) & 53 & 70 \\ 1,394,073 & 39 & 53 \\ 1,340,605 & 89 & 96 \\ 1,338,447 & 56 & 70 \\ 1,247,565 & 75 & 92 \\ 1,217,425 & 63 & 94(28) \\ 1,202,343 & 95 & 99 \\ 1,123,540 & 71 & 89 \\ 1,070,836 & 84 & 94 \\ 1,060,306 & 49 & 60 \\ 1,057,327 & 59 & 72\end{array}$

65 (24)

$70(24)$

78

48

91 (24)

64

93

54

$53(24)$

55

61 (24)

$\begin{array}{ll}91 & 99 \\ 40 & 60\end{array}$

$\begin{array}{ll}91 & 99 \\ 40 & 60\end{array}$

$52 \quad 66(28)$

54

48

78

70

53

96

70

92

$94(28)$

99

89

60

72

* Based on Kaysen \& Turner, Antitrust Poltcy: An Economic and Legal ANALYSIS 275-80 (1959).

$\dagger$ Values of shipments stated within parentheses are estimated.

\$ Where impossible to compute the concentration ratio for $20 \mathrm{firms}$, the number of firms used is given parenthetically. 


\section{APPENDIX III}

Examples of Extreme Concentration in American Manufacturing Industries*

Industry

Concentration Ratio $\uparrow$

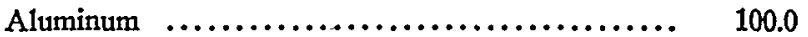

Tin cans and other tinware $\ldots \ldots \ldots \ldots \ldots \ldots \ldots . .95 .3$

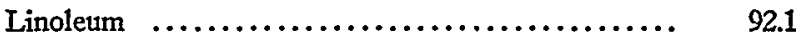

Copper smelting and refining $\ldots \ldots \ldots \ldots \ldots \ldots \ldots . \quad 88.5$

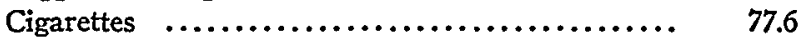

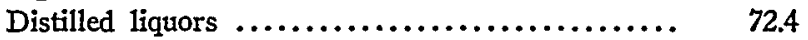

Plumbing equipment and supplies ............ 71.3

Rubber tires and tubes .................. 70.3

Office and store machines and devices ........... 69.5

Motor vehicles .......................... 68.7

Biscuits, crackers, and pretzels .............. 67.7

Agricultural machinery $\ldots \ldots \ldots \ldots \ldots \ldots \ldots \ldots \ldots .6 .6 .6$

Meat products $\ldots \ldots \ldots \ldots \ldots \ldots \ldots \ldots \ldots \ldots \ldots . .64 .0$

* From FTC, Report on the Concentration of ProducTIVE FACIIITIES 17 (1947).

i Per cent of industry's net capital assets held by three largest firms. 